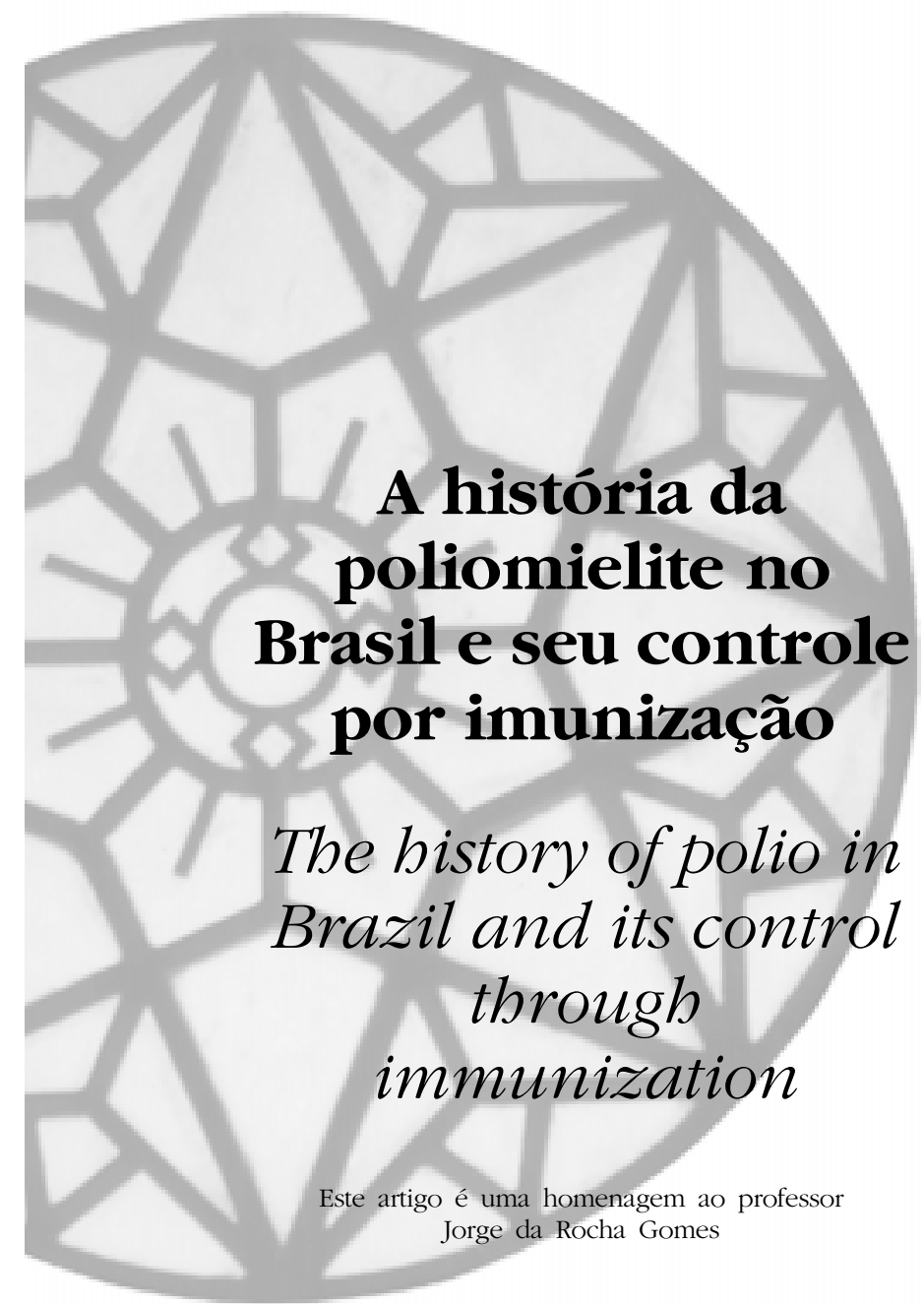

André Luiz Vieira de Campos

Professor do Departamento de História das universidades Federal Fluminense (UFF) e do Estado do Rio de Janeiro (UERJ)

camdrepo@alternex.com.br

Dilene Raimundo do Nascimento

Doutora em história social, pesquisadora da Casa de Oswaldo Cruz (COC/Fiocruz), docente no programa de Pós-Graduação em História das Ciências da Saúde (COC/Fiocruz) dilene@coc.fiocruz.br

Eduardo Maranhão

Médico, sanitarista, epidemiologista, vacinologista Fundação Oswaldo Cruz/Ministério da Saúde emaranhao@hotmail.com
CAMPOS, A. L. V. de; NASCIMENTO, D. R. do e MARANHÃO, E.: 'A história da poliomielite no Brasil e seu controle por imunização'. História, Ciências, Saúde - Manguinhos, vol 10 (suplemento 2): 573-600, 2003.

O presente artigo analisa as discussões e ações científicas e políticas em torno da questão da poliomielite no Brasil ao longo do século XX, examinando as questões que desenharam a política de controle da doença e resultaram nos dias `nacionais de vacinação, instituídos em 1980.

PALAVRAS-CHAVE: poliomielite, história, Brasil, políticas de saúde, epidemias, vacinação.

CAMPOS, A. L. V. de; NASCIMENTO, D. R. do e MARANHÃO, E.: 'The history of polio in Brazil and its control through immunization'. História, Ciências, Saúde-Manguinhos, vol 10 (supplement 2): 573-600, 2003.

The article analyzes the scientific and political discussions and activities surrounding the problem of polio in Brazil during the twentieth century. It examines the issues that shaped disease control policy and led to the 1980 introduction of National Vaccination Days.

KEYWORDS: polio, history, Brazil, bealth policy, epidemics, vaccination. 


\section{Introdução}

S e, na primeira metade do século XX as discussões sobre a $\checkmark$ poliomielite no Brasil se davam basicamente no âmbito médico e giravam principalmente em torno de modelos científicos explicativos da doença e sua forma epidêmica de incidência, na segunda metade do século, a aquisição de novas tecnologias — vacina, vigilância epidemiológica e diagnóstico laboratorial do poliovírus - deslocou o âmbito da discussão para a área da saúde pública e possibilitou o estabelecimento de políticas de controle da doença no país.

Procuramos, neste artigo, identificar os primeiros registros de surtos dessa doença no Brasil e os modelos científicos para sua compreensão nas primeiras décadas do século XX. Algumas epidemias e as respostas sociais que provocaram são estudadas à luz das sugestões de Charles Rosenberg, que analisa o episódio epidêmico como 'incidente dramático'. A identificação de um novo modelo científico para a pólio, ou seja, a reorientação de sua concepção como uma doença entérica, na década de 1940 - aliada ao desenvolvimento da técnica de cultura em tecido do poliovírus - abriu a possibilidade de elaboração de uma vacina que se tornou realidade na década de 1950, com o registro de duas vacinas eficazes contra a poliomielite: a Salk e a Sabin.

Analisamos, a partir daí, os desdobramentos possíveis na história da poliomielite no Brasil em direção ao seu controle, isto é, os caminhos que levaram, primeiramente, ao plano nacional de controle da doença, e, posteriormente, ao projeto de erradicação da poliomielite, iniciado pelo seu controle efetivo a partir de 1980, com os dias nacionais de vacinação.

As fontes utilizadas foram, principalmente, artigos científicos, depoimentos orais, documentos oficiais e matérias jornalísticas.

\section{Modelos científicos da poliomielite no início do século $\mathbf{X X}$}

Enquanto o higienismo e a bacteriologia conquistavam vitórias sobre as doenças infecciosas, a poliomielite desafiava médicos e cientistas, pois, além de não se enquadrar no modelo higienista que associava sujeira e pobreza à doença, o laboratório não foi capaz de decifrá-la até meados do século XX (Rogers, 1996, p. 2).

No Brasil, embora existam referências a casos esporádicos de poliomielite nas últimas décadas do século XIX, a primeira descrição de um surto foi feita pelo pediatra carioca Fernandes Figueira, em 1911. Pouco depois, em 1917, Francisco de Salles Gomes Júnior descreveu outro surto em Vila Americana, estado de São Paulo. Assim como havia concluído Figueira no estado do Rio de Janeiro, Salles Gomes foi categórico ao afirmar que os casos de Vila Americana já mereciam ser classificados como epidemia. Seus argumentos eram semelhantes aos do pediatra carioca: o número de casos crescia de forma constante e 
${ }^{1}$ Pelo artigo 231 da Lei 1596, de 29.12.1917, que reformulou o Serviço Sanitário de São Paulo, a poliomielite foi considerada de notificação obrigatória no estado. repetiam-se os padrões observados em epidemias internacionais (Gomes Jr., 1919).

Um dos resultados da epidemia de 1917 foi a lei que tornava a poliomielite doença de notificação compulsória no estado de São Paulo. ${ }^{1}$ Com isso, apontou Salles Gomes (idem, p. 27), as autoridades sanitárias poderiam promover "o isolamento dos pacientes e as mais rigorosas precauções no que diz respeito às secreções nasais e bucais, fazendo desinfetar todos os objetos que por eles tinham sido contaminados e fazendo proceder uma rigorosa polícia de focos ou viveiros de moscas".

Observa-se que Gomes mostrou-se preocupado com as "secreções nasais e bucais" dos pacientes, sugeriu o "isolamento" dos mesmos e reivindicou uma "rigorosa polícia de focos ou viveiros de moscas" (grifos nossos). Por meio do estudo de Figueiras, somos informados de que este médico repetiu em 1911, no Rio de Janeiro, as experiências de laboratório feitas em macacos por Flexner e Clark no ano anterior (Figueira, op. cit.).

Tanto Figueira quanto Salles Gomes estavam familiarizados com os trabalhos de Flexner e Lewis sobre a poliomielite. Aliás, segundo registram os periódicos especializados, os médicos brasileiros mostravam-se bastante atualizados com a bibliografia internacional de ponta. No Rio de Janeiro, o Brasil Médico encarregava-se de divulgar "os últimos estudos e observações sobre a paralisia espinhal infantil". Por exemplo, um artigo de Flexner e Lewis, publicado em 1910, mostrava que o vírus da pólio era "encontrado em grande quantidade na membrana mucosa na nasofaringe", o que os levou a concluir que as secreções da garganta e do nariz "devem ser uma das fontes principais do contágio" (Brasil Médico, XXIV, 47, 1910, pp. 467-8).

Flexner sustentou que o microorganismo da poliomielite podia ser transmitido de um doente para um macaco Rhesus, e deste para um outro; além disso, este 'micróbio' era um vírus filtrável. O cientista argumentou que o poliovírus viajava pelos nervos diretamente, após entrar no corpo; portanto, a poliomielite seria uma doença neurológica. Como o contágio, segundo seu modelo, se dava pelas secreções nasais, seu modo de transmissão seria típico das doenças respiratórias — daí a recomendação para o isolamento dos pacientes (Rogers, op. cit, pp. 21-3).

Um outro modelo explicava a disseminação da poliomielite por um vetor: a mosca doméstica. O modelo do vetor tinha a vantagem de utilizar mecanismos explicativos da entomologia médica e, ao mesmo tempo, se associava ao 'velho higienismo', pois enfatizava a relação entre doença e sujeira. Além disso, o modelo era muito cômodo por duas outras razões: por um lado, era mais fácil para divulgar os então recentes conceitos da ciência médica, pois uma mosca podia ser vista, ao passo que um 'gérmen', não; por outro, servia também para explicar por que os casos de poliomielite eram encontrados tanto em cortiços como em 'casas higiênicas' da classe média (Rogers, op. cit., p. 144). 
Mas havia também um terceiro modelo: aquele que enfatizava a relação entre meio ambiente e poliomielite, mostrando que muito da epidemiologia do século XIX continuava a ser empregada para explicar a poliomielite epidêmica no século XX. Esse modelo sugeria que a doença poderia ser transmitida por poeira, leite contaminado, objetos tocados pelos doentes ou ainda por animais domésticos.

Dentre esses modelos, o de Flexner tornou-se ortodoxia até a década de 1940. Entretanto, como veremos adiante, em ocasiões dramáticas como uma epidemia, explicações e terapias derivadas dos outros modelos não eram descartadas por médicos e autoridades, o que mostrava a incapacidade de quaisquer dos modelos de dar conta daquela então 'doença misteriosa'.

\section{Epidemias e dilemas}

Após as primeiras epidemias no Rio de Janeiro e em Americana, surtos de certa magnitude foram registrados apenas a partir das décadas de 1930 e 1940. No Rio de Janeiro, em 1953, ocorreu a maior epidemia até então registrada no país (Brasil, Ministério da Saúde, 1988). Com a generalização das epidemias, tornou-se possível, pela imprensa, perceber a ansiedade da população, o novo desafio que a situação colocava para médicos e autoridades, bem como as respostas que estes receberam da sociedade brasileira.

Charles Rosenberg (1992) caracterizou as epidemias como 'incidentes dramáticos' que seguem um 'roteiro' dividido em 'atos', como uma peça de teatro. Ao primeiro deles chamou de 'negação e progressiva revelação'. Historicamente, é muito comum que a primeira reação de uma sociedade diante de uma epidemia seja negá-la, para admiti-la somente quando se torna impossível ignorar sua presença. Isso por uma série de razões: desde o medo de prejuízos econômicos e políticos, até a simples negação psicológica do perigo. Um outro padrão repetese historicamente: ao se admitir publicamente uma epidemia, é freqüente que se busquem 'culpados' pelo mal.

O segundo ato se passa quando autoridades e médicos procuram explicações para o acontecimento. Por muitos séculos esse quadro explicativo foi apenas religioso e moral. Entretanto, a partir da Idade Moderna, as explicações religiosas passaram a conviver com as explicações científicas, sendo essa eclética mistura fundamental para administrar as respostas sociais às doenças epidêmicas no Ocidente.

O terceiro ato consistiria na(s) resposta(s) pública(s), geralmente múltiplas, suscitadas pela epidemia - rituais religiosos, medidas policiais e sanitárias etc. - , que representam um mesmo papel: a atitude clara de solidariedade e a autodefesa de uma comunidade diante do perigo. As respostas a uma epidemia nos permitem observar os valores sociais vigentes, enquanto conflitos sobre prioridades entre elas permitem alguns insigths sobre estruturas de autoridade e de crença. 
O quarto e último ato seria o que vem depois do término da epidemia, relacionando-se com a reflexão que comunidade faz sobre sua experiência: $\mathrm{O}$ que se aprende com ela? Pode ter servido para criar algumas medidas de saúde pública permanentes? (Rosenberg, op. cit., pp. 278-304).

Vamos utilizar as sugestões de Rosenberg para analisar algumas reações da sociedade brasileira diante das epidemias de poliomielite que se sucederam, a partir da década de 1930.

Entre janeiro e julho de 1937 deu-se uma epidemia em Santos, estado de São Paulo (Vieira, 1940). Observamos, como sugeriu Rosenberg, que a primeira reação das autoridades foi a de negar a existência do perigo. Há registros na imprensa de 'notícias alarmantes', que "corriam de boca em boca até fora dos limites de Santos", sobre um surto epidêmico da 'terrível moléstia'. Diante desse quadro, o delegado de Saúde de Santos, Castro Simões, foi ao jornais assegurar não haver motivos para alarme, pois o que ocorria era apenas "uma exacerbação da moléstia que existe endêmica em Santos", "não se tratando portanto de uma epidemia" ( O Estado de S. Paulo, 30.7.1937, p. 4).

Apesar de negar a ameaça, Castro Simões procurou esclarecer a população sobre a doença. Sua fala é muito significativa, pois revela a convivência de diferentes modelos da doença e a incapacidade da medicina científica, naquele momento, dar uma resposta eficaz à ansiedade pública. O médico recorreu ao modelo de Flexner, ao afirmar ter o poliovírus "eleição para os centros nervosos motores", sendo encontrado "nas secreções da garganta e do nariz". Entretanto, a mesma autoridade sanitária não descartou outros paradigmas médicos, ao apontar, referindose ao vírus, "uma grande resistência a influências exteriores, conservando sua vitalidade nas poeiras, alimentos (leite) e objetos de uso". Para tranqüilizar a população, afirmou que, "felizmente, a predisposição para a moléstia é pequena", além da doença não ser muito contagiosa, como podia ser comprovado pelo raro número de casos de doentes numa mesma familia (O Estado de S. Paulo, 30.7.1937, p. 4, grifos nossos).

Em 1939, ocorreu no Rio de Janeiro, então capital da República, uma importante epidemia de poliomielite. Escrevendo três anos após o episódio, Décio Parreiras (1942, p. 155), diretor do Serviço de Saúde do Distrito Federal, reconheceu sua dimensão, comparando o número das notificações oficiais entre 1920 e 1938 com o número de casos de 1939: as cifras deste último ano foram quase 6,5 vezes maiores do que nos 18 anos do período anterior. Ainda mais: o número de óbitos significou "mais de um terço de falecimentos por essa doença registrados nos últimos vinte anos de observação". Segundo Parreiras, esses dados eram "justificadores do pânico e grande alarme em que viveu a cidade do Rio de Janeiro neste período de epidemia".

Entretanto, naquela ocasião, podemos encontrar, no mesmo dia e jornal, declarações conflitantes entre autoridades sobre o assunto. Enquanto, por meio do gabinete do ministro da Educação e Saúde e do 
${ }^{2}$ A notificacão compulsória no nível federal deu-se for força do decreto $\mathrm{n}^{\circ} 16.300, \mathrm{~d}$ 1923. diretor do Departamento Nacional de Saúde Pública, vinham declarações no sentido de 'tranqüilizar' a população 'preocupada' (por exemplo, afirmando que o "surto corrente não tem as proporções de uma epidemia"), Décio Parreiras fazia uma 'confirmação terminante' de que se tratava do "maior surto desta enfermidade já verificado" na Capital (Correio da Manhã, 19.10.1939, pp. 3-4). As autoridades federais, ainda buscando negar o perigo, sustentavam que a doença era de notificação compulsória e, portanto, "todos os casos verificados (são) mantidos em isolamento". ${ }^{2}$ Se, por um lado, o Ministério da Educação e Saúde recomendava que a vida escolar seguisse sua normalidade, por outro, cautelosamente, sugeria que as crianças fossem "afastadas de aglomerações da praça pública, da praia e de outras de mesma natureza" (Correio da Manhã, 19.10.1939, p. 3).

Poucos dias depois dessa comunicação, um médico buscou responsáveis pelo 'pânico desnecessário': Figueiredo Rodrigues responsabilizou o "amor materno exaltado da nossa raça" pelas proporções impressionantes do alarme que o fato causou no Rio de Janeiro. Afirmando não haver "motivo de alarme mas de preocupação", Rodrigues sugeriu como "medida de necessidade o fechamento de todas as classes escolares, onde tenha havido casos" (Correio da Manhã, 25.10.1939, p. 3). Contradizendo a opinião de Rodrigues, o superintendente geral de Educação e Higiene Escolar do Distrito Federal afirmou não existir "um único caso confirmado de paralisia infantil entre alunos", e que eventuais casos de "comunicantes" seriam "imediatamente afastados" (Correio da Manhã, 22.10.1939, p. 2).

Esses desencontros sugerem a frustração de médicos diante da incapacidade da medicina científica dar uma resposta à poliomielite, tal como já havia feito com outras doenças infecciosas. Ao mesmo tempo, indicam a permanência de crenças e valores impregnados de paradigmas pré-bacterianos, não apenas entre leigos mas entre os próprios médicos.

Um exemplo precioso disso se encontra no estudo de Décio Parreiras sobre a epidemia de 1939. Parreiras (1940, pp. 4-5, 2, 9), aceitando a hipótese da contaminação pelas vias aéreas superiores (modelo de Flexner), achava no entanto que se devia levar em consideração "outros fatores além da virulência do gérmen e da maior ou menor receptividade individual". Segundo o médico, a "umidade do ar e a eletricidade atmosférica", além das variações da estação e do "campo magnético", eram variáveis que determinavam maior ou menor probabilidade "da infecção por gotículas de origem respiratória”. Aceitando a interferência de tais variáveis, Parreiras concluía que o declínio da epidemia de 1939 não devia ser tributado a "nenhuma medida de ordem sanitária", mas a alterações atmosféricas ambientais que a cidade conheceu a partir de outubro.

Diante de tantos desencontros, um registro merece destaque: no auge da epidemia carioca, um anônimo autor clamava pela verdade e denunciava: "a obscuridade que ainda reina" sobre todos os 
${ }^{3} \mathrm{O}$ microscópio eletrônico permitiu aos pesquisadores observar $\mathrm{O}$ vírus da poliomielite, até então somente uma hipótese construída em filtragem. aspectos da poliomielite significava que "não se pode adotar para sua profilaxia e defesa coletiva medidas de absoluto rigor científico, como se faz com segurança para a febre amarela ou a peste bubônica". Perguntava ainda o autor: "Qual é o agente da poliomielite? Um gérmen de presunção, isto é, invisível e imponderável. Qual a sua via de transporte? Incógnita. E o meio de tratá-la? Tudo hipotético. Isto é o que se deve incutir no espírito público, para que ninguém confie em medidas que não podem ser prescritas com segurança." E concluía: "Para as moléstias infecciosas de natureza obscura só há uma profilaxia, também empírica, que consiste em diminuir os contatos das pessoas suscetíveis, no caso as crianças. O grande problema neste momento é tranqüilizar a população, mas sem promessas falazes, que a ciência não autoriza" (Correio da Manhã, 21.10.1939, p. 4).

\section{Novos conhecimentos científicos: um novo modelo para a pólio}

Durante a década de 1940, o modelo de Flexner foi minado pelo avanço da virologia e do surgimento do microscópio eletrônico. ${ }^{3}$ Como vimos, aquele modelo sugeria que o poliovírus invadia o corpo pelo nariz ou pela boca e viajava diretamente para o cérebro e medula espinhal através do sistema nervoso. Esse modelo implicava a impossibilidade de se pensar numa vacina, pois reconhecia-se que qualquer tentativa desenvolvida com esse fim a partir de células nervosas poderia também trazer infecção cerebral.

Em 1948, John Enders e sua equipe iniciaram experiências que os levaram a cultivar o vírus da poliomielite em outros tecidos que não os nervosos. No início da década de 1950, cientistas concluíram que o poliovírus apenas ocasionalmente atacava os tecidos nervosos. A poliomielite, antes classificada como doença neurológica de contágio respiratório, passou a ser classificada como doença entérica. A partir desses novos conhecimentos, a possibilidade de uma vacina tornou-se real (Rogers, op. cit; Karlen, 1996).

No Brasil, os periódicos científicos registraram o debate sobre o novo modelo, como, por exemplo, o artigo em que Barros Barreto (1953) repensa a poliomielite como doença de clima temperado. Antes, acreditava-se que a poliomielite predominava em países frios, manifestando-se por grandes epidemias; ao passo que nos trópicos os casos paralíticos eram esporádicos e as epidemias nunca atingiam grande magnitude. Esse quadro foi modificado, tendo em vista as altas taxas de infecções subclínicas encontradas nos países tropicais. Deve-se tal fato à forma endêmica que a poliomielite assumiu nesses países, uma vez que a distribuição regular da doença durante o ano e as precárias condições de saneamento permitiam que as crianças entrassem em contato com o vírus desde os primeiros meses de vida, produzindo imunidade. Esse dado também explicaria 
${ }^{4}$ Note-se que Barreto usou o conceito de controle, e não de erradicação. Os grifos são dos autores. o fato de a poliomielite atacar, nos países desenvolvidos, crianças de idade mais avançada (entre cinco e nove anos) e mesmo adultos (sendo a letalidade nove vezes maior entre estes), enquanto nos países subdesenvolvidos era muito rara em crianças maiores de seis anos. Barreto concluiu o artigo de forma otimista, ao indicar que as novas descobertas abriram as possibilidades do controle da doença e ao apontar que estava "na imunização a chave do problema da poliomielite". Segundo ele, dois caminhos estavam abertos "para o desenvolvimento de uma vacina: um, através de um vírus vivo atenuado; e um segundo, a partir de vírus mortos, caminho este em que se tem feito mais experiências, sendo conhecida a tentativa de Salk" (Barreto, op. cit., pp. 25-6, 28, 31). ${ }^{4}$

A grande imprensa também noticiou de forma otimista as últimas descobertas do laboratório, e por seu intermédio percebemos como o conceito de controle por meio de uma vacina começava a circular nos meios científicos e junto à opinião pública. Em março de 1953, o prêmio Nobel W. M. Stanley anunciava que, "dentro de dez anos, a paralisia infantil será tão facilmente controlada como a varíola, por meio de vacinas" (Correio da Manhã, Segundo Caderno, 29.3.1953, p. 5). O mesmo cientista também comunicou "que pela primeira vez fora isolado e identificado no laboratório o vírus da poliomielite e se conhece com certeza seu tamanho e forma" (Correio da Manhã, 12.11.1953, p. 1). De acordo com Stanley, 'o modo mais lógico' de imunização contra a poliomielite seria "através do emprego de um vírus ativo modificado pela via natural de contaminação, isto é, via bucal" (Correio da Manhã, Terceiro Caderno, 12.7.1953, p. 4). Notamos aqui que já se ensaiava uma disputa entre os partidários de uma vacina produzida com vírus mortos e outra, com vírus atenuados.

Entretanto, apesar das notícias otimistas, a poliomielite continuava a ser um grave problema de saúde pública naquela década e, em ocasiões dramáticas, como uma epidemia, os velhos temores e conceitos sobre a doença voltavam a assombrar. Um bom exemplo podemos encontrar na imprensa carioca durante a epidemia de 1953.

\section{A epidemia de 1953 no Rio de Janeiro: ainda os velhos dilemas}

Tal como em 1939, a primeira reação registrada na imprensa foi de negação da epidemia. No primeiro dia do ano de 1953, o Correio da Manhã estampava a manchete: "Não há epidemia de paralisia infantil no Rio". As autoridades do Departamento de Higiene da Prefeitura reforçavam essa estratégia e, além de negarem o 'suposto surto', afirmavam: "A rigor, não há nem mesmo entre nós paralisia infantil endêmica, pois as notificações que aparecem de onde em onde são pura e simplesmente casos esporádicos" (Correio da Manhã, $1^{\circ} \cdot 1.1953$, p. 1). 
Ainda em janeiro, as autoridades continuavam a negar o surto; porém, ao contrário do divulgado anteriormente, reconheciam a poliomielite como uma doença endêmica no país. Ponderava-se que o surgimento de dois casos na praia de Botafogo não era motivo para o "alarde que se tem feito", uma vez que, como a doença já havia sido implantada no Brasil, era "normal o surgimento de um ou outro caso". Desdenhando o conhecimento médico de ponta, usavase ainda como argumento para negar a epidemia a velha noção que via a poliomielite como uma 'doença do frio', e ironicamente lembrava-se que "este elemento epidemiológico (está) em falta nesta capital" (Correio da Manhã, 23.1.1953, p. 4). O Serviço de Informação Sanitária da Prefeitura informava não haver motivos para alarde quanto ao "propalado surto", já que "um ou outro caso registrado na capital são de doentes bem conhecidos", sendo "a maioria dos doentes internados em nossos hospitais (originários) de outros estados da federação" (Correio da Manhã, 31.1.1953, p. 2).

Mesmo assim a pressão da opinião pública chegou à imprensa e aos corredores da Câmara Municipal. Notícias de que reinava no Rio de Janeiro uma 'grande inquietação' tornavam-se mais freqüentes, indicando que a população suspeitava "que as informações oficiais estejam pecando por otimismo", pois "quase todos no Rio conhecem uma família onde houve alguma vítima de paralisia infantil" (Correio da Manhã, 2.7.1953, p. 4). Na Câmara, vereadores denunciavam o "alarmante surto no Distrito Federal". O vereador João Machado constatou no Hospital Jesus que "o número de crianças internadas para tratamento nos primeiros cinco meses de 1953 é quase igual ao de todos do ano passado" (Correio da Manhã, 8 - 9.5.1953, p. 7).

Diante das negativas das autoridades e do temor das famílias, o principal jornal da cidade solicitou a opinião de médicos. O "eminente professor" Dagmar Chaves, catedrático de ortopedia infantil da Faculdade de Medicina, não quis se comprometer, afirmando que "não vem aumentando a incidência do mal de maneira assustadora, o que é efetivo e real é que vem progredindo". Porém, acreditava não haver "razão para alarme mas existem sem dúvida motivos para preocupação" (Correio da Manhã , 2.4.1953, 3, grifos nossos). Entretanto, no mesmo dia e no mesmo jornal, o especialista Oswaldo Pinheiro de Campos foi enfático e objetivo ao admitir a existência de uma epidemia na cidade. Segundo Campos, "é muito mais útil reconhecer e apontar uma verdade, embora desagradável, do que a encobrir com artifício de lógica" (Correio da Manhã, 2.4.1953, p. 4). Decerto preocupado em "acalmar a população", o pediatra Mário Olinto buscou minimizar o perigo, afirmando que, comparativamente aos de 1910 e 1939, o surto de 1953 "não é mais intenso em face do aumento vertiginoso da população" (Correio da Manhã, 23.6.1953, p. 3).

Frente a essas declarações, da atitude da Câmara Municipal e da pressão da população, que "chegava quase ao pânico", o Serviço de 
Informação Sanitária da Prefeitura acabou reconhecendo a existência de um surto de "alguma gravidade", ressaltando porém não haver motivo para pânico, desde que fossem seguidos os "preceitos de higiene indicados, como a abstenção de aglomerações, principalmente em recintos fechados" (Correio da Manhã, 12.5.1953, p. 3). Em junho, o secretário de Saúde e Assistência admitiu 450 casos notificados "desde o início do surto, dos quais 27 foram fatais". Esse número correspondia ao dobro do total do ano de 1949, "quando se registrou grande surto" (Correio da Manhã, 20.6.1953, p. 7). No mês seguinte, uma autoridade sanitária confirmava que a epidemia mostrava-se "em elevação lenta desde o início do ano até a presente data" e reconhecia não existir, "aqui ou em qualquer outro lugar do mundo, medida de prevenção específica com relação à paralisia infantil" (Correio da Manhã, 11.7.1953).

Assim, vemos repetirem-se em 1953 algumas práticas já presenciadas em 1939. Por exemplo, a campanha de esclarecimento à população iria demonstrar a pluralidade de explicações, tratamentos e prevenção que circulava entre médicos, autoridades e a população. Eduardo Morgado alertava que "o contágio pode ser do doente à pessoa sã no ato de tossir, espirrar, bem como pelas fezes ou por meio de alimentos, da água, do leite ou de objetos contaminados, sendo a mosca e outros insetos os vetores. Os aparelhos digestivos ou respiratório são, pois a porta de entrada do vírus no organismo humano" (Correio da Manhã, 2.8.1953, p. 4, grifos nossos). O mesmo médico advertia que a sujeira era a causa principal da doença, pois, "no verão as praias ficam repletas de banhistas que fazem verdadeiros piqueniques, deixando as praias sujas com restos de alimentos" (Correio da Manhã, Quinto Caderno, 19.7.1953, p. 4). Reforçando o leque de possibilidades, o secretário de Saúde, Álvaro Dias, apontava a água e o leite como perigosos condutores do vírus da poliomielite (Correio da Manhã, 20.6.1953, p. 7). Ou seja, nenhuma possibilidade era descartada.

Diante de tanta incerteza e medo, as mais inusitadas profilaxias seriam tentadas, muitas vezes simplesmente refletindo algum recente (e temporário) sucesso médico. Um exemplo evidente foi a decisão do Serviço de Profilaxia de Malária de dedetizar todas as casas da pequena Vila Ransard, no interior de São Paulo, onde um surto havia sido detectado em 1953. Com certeza tal medida não apenas refletia a utilidade simbólica do modelo do vetor e resquícios do velho higienismo, mas também, e talvez principalmente, os sucessos obtidos com a campanha de erradicação da malária. Confiando nesse 'método preventivo', a população, "que se mostrava alarmada com a doença, está controlada, graças às providências das autoridades" (Correio da Manhã, 31.10.1953, p. 9).

O uso do DDT com certeza não contribuiu em nada para debelar o surto da doença, mas certamente serviu como ritual científico para tranqüilizar a população. Na tentativa de dar uma resposta a uma 
doença para a qual não havia até então nenhuma alternativa eficiente, qualquer método que trouxesse algum conforto à população podia ser utilizado, inclusive a antiga prática de culpar estrangeiros pela disseminação do mal. Não foi outra coisa que fez um articulista em plena epidemia carioca de 1953, sugerindo que as autoridades deveriam exercer "vigilância sobre indivíduos que vêm de lugares onde já se radicou a doença, como os EUA". Prosseguindo, apontava terem sido registrados quatro óbitos debitados à poliomielite em Copacabana e indagava: "Estes casos em Copacabana se verificam em brasileiros residentes ou em estrangeiros chegados há pouco e provavelmente infectados em seu país de origem? Tais fatos precisam ser esclarecidos para julgar sobre a conveniência ou não de ser estabelecida a vigilância sanitária nos imigrantes de lugares infestados por paralisia" (Correio da Manhã, 12.7.1953, p. 4, grifos nossos).

No limite, todas essas manifestações refletiam a ansiedade de médicos, autoridades, doentes, seus familiares e da população em geral diante de uma doença que ainda representava uma terrível ameaça. As palavras do pediatra Mário Olinto são, neste sentido, emblemáticas daquele drama. Olinto não conseguiu esconder seu desânimo diante das campanhas de esclarecimento que "têm servido para alarmar as mães que imploram, diariamente, do médico, meios para evitar a doença em seus filhos (e) vivem num sofrer constante contra o qual o médico se sente impotente para aconselhar, uma vez que, conscientemente, nada pode dizer" (Correio da Manhã, 23.6.1953, p. 3).

Àquela altura, nos Estados Unidos, as pesquisas que perseguiam uma vacina contra a poliomielite avançavam.

\section{A busca por uma vacina}

No intervalo de quarenta anos entre o isolamento do poliovírus em macacos, conseguido por Landesteiner e Popper em 1908, e o desenvolvimento das técnicas de cultura em tecido, foi feito considerável progresso para o entendimento da poliomielite (Shaeffer, 1953). Ficou evidenciado que o vírus se multiplicava no trato gastrointestinal e que a infecção podia ser transmitida pela via fecal-oral, isto é, transmissão através da água ou produtos contaminados por fezes e ingeridos pela boca.

A época áurea do desenvolvimento de vacinas iniciou-se em 1949, com a descoberta da propagação de vírus em culturas de células (Bodian, 1952,1949; Beale, 1996). Embora muito se tivesse aprendido sobre a poliomielite e o vírus que a causava, até 1949 não existia grande expectativa sobre a possibilidade de se desenvolver a prevenção com as técnicas então disponíveis. Foi a publicação de um artigo de Enders (1949) e colaboradores na Science, em que era descrito o cultivo do poliovírus em culturas de tecido humano, que forneceu a ruptura e o achado ansiosamente procurado pelos cientistas que pesquisavam uma vacina contra poliomielite. 
${ }^{5}$ Vacina produzida com vírus mortos, isto é, vírus que, por manipulação, perdem a capacidade de se replicar e transmitir; a vacina Salk injetável contra a poliomielite é também chamada IPV.

${ }^{6}$ Uma molécula capaz de desencadear uma resposta específica com um anticorpo ou célula.
Com a disponibilidade das técnicas de cultura de tecidos, fabricar vacinas contra a poliomielite tornou-se uma possibilidade real, e um apreciável número de laboratórios começou a trabalhar para conseguir tal finalidade. Salk e colaboradores, assim como Milzer e colaboradores, escolheram prosseguir em direção à vacina inativada, ou seja, feita a partir de vírus mortos; enquanto Cox, Koprowski e Sabin optaram por obter uma vacina de vírus vivo atenuado (Robbins, 1999, pp. 14-5; Koprowski et al., 1996).

\section{A vacina inativada ${ }^{5}$}

Usando o vírus desenvolvido em cultura de tecido de rins de macaco, Salk e seus colaboradores desenvolveram estudos seguros que geravam imunidade em animais e, em 1953, aplicaram os primeiros testes em humanos. Salk apresentou a hipótese de que, uma vez o hospedeiro sensibilizado com uma dose adequada do antígeno, ${ }^{6}$ o efeito de resposta poderia ocorrer devido ao desafio com o antígeno inativo ou com o vírus vivo. No desafio com o vírus vivo, o anticorpo devia ser formado muito rapidamente para prevenir a viremia, ou seja, a presença de vírus no sangue, e, assim, a paralisia. Embora a viremia tenha sido demonstrada em macacos, somente muito mais tarde foi demonstrada em humanos. Logo em 1954, os dados foram considerados suficientes para garantir a realização daquele ensaio.

Francis, da Escola de Saúde Pública da Universidade de Michigan, dirigiu o projeto que foi o maior experimento do tipo em qualquer tempo. O ensaio envolveu cerca de dois milhões de crianças de comunidades de todas as partes dos Estados Unidos, além de várias outras do Canadá e Finlândia. Os resultados foram apresentados em 12 de abril de 1955, e concluiu-se que a vacina era segura e eficaz num nível de cerca de $70 \%$, e que a efetividade estaria correlacionada com a potência, quando medida pela resposta de anticorpos em crianças. Fundamentado na evidência obtida nesse ensaio e nos dados apresentados pelos pesquisadores, o produto de seis laboratórios foi licenciado poucos dias após a divulgação dos resultados do ensaio de campo (Hinman et al., 1995). O interesse pela vacina foi grande, e muitas comunidades organizaram programas específicos de vacinação.

Entretanto, pouco após a vacina ter se tornado disponível, foram notificados casos de doença paralítica em vacinados. Como o intervalo entre a vacinação e o início da doença correspondia ao período de incubação da poliomielite, e como a paralisia ocorria no membro inoculado, suspeitou-se de que aqueles casos fossem causados por vírus ativos residuais. Uma investigação epidemiológica revelou que quase todos os casos ocorreram em crianças que receberam a vacina produzida pelo laboratório Cutter, no episódio conhecido como 'Incidente Cutter'.

O Serviço de Saúde Pública dos Estados Unidos suspendeu imediatamente a vacinação, recolheu a vacina do laboratório Cutter e 
${ }^{7}$ Vírus atenuados: vírus que sofreram manipulação por técnicas laboratoriais, reduzindo sua capacidade de produzir a doença; a vacina Sabin oral contra a poliomielite também chamada OPV.

\footnotetext{
${ }^{8}$ Vacina que tem um só tipo de poliovírus e conseqüentemente só protege para este tipo de poliovírus.
}

desencadeou intensa investigação, incluindo uma cuidadosa revisão dos regulamentos governamentais de produção e das técnicas empregadas pelos laboratórios produtores. $\mathrm{O}$ vírus ativo foi isolado de vários lotes de vacina. Como resultado disso, novas exigências foram introduzidas nos testes de segurança.

O laboratório Cutter havia produzido a menor quantidade da vacina entre os laboratórios produtores, e foi demonstrado que os produtos das outras empresas eram seguros. Cerca de 260 casos de poliomielite foram identificados graças a esse incidente. Destes, 94 tinham sido vacinados, 126 foram provocados por contatos familiares e quarenta por contatos comunitários. Dos 260 casos, 192 ficaram paralíticos, mas não houve mortes (Nathanson e Langmuir, 1955; Beale, op. cit.). Surpreendentemente, o 'Incidente Cutter' não abalou a confiança da população na vacina, e, quando se retomou a vacinação, esta foi bem- aceita.

Um importante resultado do 'Incidente Cutter' foi a criação da unidade de vigilância epidemiológica no Centro de Prevenção e Controle de Doenças dos Estados Unidos (CDC), em Atlanta, que manteve um excelente acompanhamento da poliomielite e outros programas de vacinação. Com a retomada da vacinação no país e em outros lugares, o impacto sobre a incidência da poliomielite logo se tornou evidente (Moulin, 1996).

\section{A vacina atenuada ${ }^{7}$}

A idéia de vacinas de vírus atenuados se opôs à de vacinas de vírus inativados. Aquela teve grande apelo para muitos investigadores, de vez que se presumia que uma infecção ativa reproduz de maneira mais próxima a situação natural, o que permitiria obter uma imunidade mais duradoura e produzir resistência à infecção no nível do intestino.

Havia três grupos principais de investigadores nos Estados Unidos trabalhando no desenvolvimento de uma vacina de vírus vivo atenuado contra a poliomielite: Cox, no laboratório Lederle, Koprowski e colaboradores, no Instituto Winstar, na Filadélfia, e Sabin, em Cincinnati. Apesar de Koprowski ter sido o autor do primeiro informe, publicado em 1952, sobre o uso de uma vacina de poliovírus vivo atenuado em humanos, Sabin tomou a dianteira na resolução de uma vacina efetiva. Grandes tentativas com estudos de campo em diferentes partes do mundo foram realizadas, utilizando-se variadas cepas candidatas. Como a vacina Salk tinha sido licenciada e já estava sendo utilizada amplamente nos Estados Unidos, era muito difícil realizar testes com a vacina Sabin em larga escala naquele país.

Originalmente, as vacinas Salk e Sabin eram monovalentes ${ }^{8}$ graças à interferência que ocorria entre os três tipos de vírus da vacina. Mais tarde, verificou-se que, ajustando-se as quantidades, a interferência entre os vírus podia ser superada; tornou-se então possível uma vacina 
trivalente, contendo os três tipos de vírus. Uma demonstração desse mecanismo ocorreu no ensaio de campo recomendado pela OMS, em 1957, realizado em Cingapura. Cerca de duzentas mil crianças receberam a vacina contra a poliomielite do tipo II, num esforço para cortar, por meio do mecanismo de interferência, uma epidemia do tipo I. O vírus vacinal, na verdade, parecia interferir com o vírus selvagem e mostrou-se seguro.

Naquele mesmo ano, Sabin forneceu ao professor Chumakov, do Instituto de Poliomielite e Encefalite Viral de Moscou, um suprimento de suas cepas de vírus atenuados, que foram usadas para ensaios e estudos e como embrião para a produção da vacina aplicada. Os soviéticos agiram rapidamente e em cerca de um ano aproximadamente 15 milhões de pessoas foram vacinadas sem qualquer evento adverso e com evidente efetividade. Em 1960, cerca de cem milhões de pessoas na então URSS e nos países do Leste europeu tinham recebido a vacina Sabin. Este amplo sucesso foi apresentado como prova para solicitação de licença da vacina Sabin nos Estados Unidos. Dorothy Horstmann foi convidada a visitar a URSS e os países do Leste europeu para avaliar o programa e a confiabilidade dos dados. Seu relatório favorável ajudou no licenciamento da vacina Sabin, nos Estados Unidos, em 1960. A partir daí, duas vacinas eficazes e seguras contra a poliomielite tornaramse disponíveis para uso geral: a Salk, de vírus inativo e uso injetável; e a Sabin, de vírus atenuado e uso oral (Robbins, op. cit.).

\section{Introdução da vacina antipoliomielite no Brasil}

No Brasil, a vacina Salk começou a ser utilizada a partir de 1955, por intermédio de alguns pediatras e em vacinações de amplitude muito reduzida, promovidas por secretarias estaduais e municipais de Saúde, basicamente do Rio de Janeiro e em São Paulo.

Em outubro de 1960, alguns jornais anunciavam a intensificação da imunização contra a poliomielite com a vacina Salk, uma vez que se registrava nessa época um aumento da incidência da doença em algumas capitais. Já em dezembro, os órgãos de saúde apelavam à população para que vacinassem seus filhos contra a poliomielite, ressaltando que o público não dava a merecida importância ao assunto ( $O$ Estado de São Paulo, 10.12.1960, p. 36).

Entretanto, desde janeiro de 1960 discutia-se a maior eficácia da vacina Sabin em relação à vacina Salk, tendo em vista os resultados na URSS. Oswaldo Pinheiro Campos dizia: "Não há por que negar que as vacinas do vírus vivo sejam mais eficientes e que mais dia menos dia superará totalmente a vacina Salk" ( O Estado de S. Paulo, 29.1.1960, p. 6).

A disputa entre os partidários das duas vacinas foi um dos assuntos tratados na V Conferência Internacional da Poliomielite, realizada em Copenhague entre os dias 26-28 de julho de 1960 (O Estado de S. 
${ }^{9}$ Comissão composta por Joaquim Travassos, diretor do Instituto Oswaldo Cruz; José Martinho da Rocha, catedrático de pediatria da Universidade do Brasil; Paulo de Góes, catedrático de microbiologia da Universidade do Brasil; Oswaldo Pinheiro de Campos, ortopedista; Madureira Pará, virologista; Bichat de Almeida Rodrigues, diretor do

Departamento Nacional de Saúde; Álvaro Aguiar, presidente da Sociedade Brasileira de Pediatria.

${ }^{10}$ Não cabe, nos limites deste artigo, um maior aprofundamento sobre a disputa Salk versus Sabin. Sugerimos a leitura de Moulin (1996).
Paulo, 27.7.1960, p. 9). Essa discussão no Brasil ocupou vários fóruns médicos, principalmente a Sociedade Brasileira de Pediatria e a Sociedade Brasileira de Higiene. Em 8 de abril de 1961, o Correio da Manhã noticiava que uma comissão9 designada pelo ministro Catete Pinheiro para opinar sobre as vacinas antipoliomielite posicionava-se favorável ao uso da vacina Sabin em substituição à Salk. No parecer da comissão, julgava-se que o emprego da vacina oral havia sido iniciado somente após a elaboração de cuidadoso planejamento de trabalho com a assessoria de peritos da OMS. ${ }^{10}$

Mais adiante, em julho, a Associação Médica Americana (AMA) também aconselhava o uso da vacina Sabin, argumentando que a vacina Salk não seria capaz de erradicar a enfermidade. Jonas Salk criticou fortemente tal orientação, acusando a AMA de pôr em risco a campanha de 'extinção' da poliomielite e afirmando que a vacina Sabin ainda não estava em condições de ser aplicada em massa. Salk afirmava ainda que esse posicionamento da AMA estava equivocado, por esta não dispor de dados científicos sobre a vacina que levava seu nome, até porque sua administração em massa havia erradicado a poliomielite na Suécia e na Dinamarca (Correio da Manhã, 7.1961, p. 1).

Assim, a vacina Sabin ganhava cada vez mais adeptos. Em conferência na Sociedade Brasileira de Higiene, Maurício Martins da Silva, médico brasileiro consultor da OMS em Washington, afirmava que "a vacina por via oral contra a poliomielite com vírus vivos atenuados, dada a uma coletividade que esteja enfrentando surto epidêmico da doença, pode cortar a ocorrência, normalizando a situação epidemiológica" (Correio da Manhã, 4.6.1961, Caderno 1, p. 6).

Enfim o Ministério da Saúde adotou oficialmente a vacina Sabin e iniciou em 16 de julho de 1961 a primeira experiência de vacinação em massa na cidade de Santo André, no estado de São Paulo, com a expectativa de vacinar 25 mil crianças dos municípios de Santo André, São Bernardo e São Caetano.

No Rio de Janeiro, foi realizada uma experiência-piloto no Instituto Fernandes Figueira, onde foram vacinados os filhos dos funcionários na faixa etária de quatro meses a seis anos, com o intuito de preparar médicos e enfermeiros para o início da vacinação em massa, o que ocorreu de 28 de agosto a 2 de setembro, em Petrópolis. Essa campanha, cuja expectativa era vacinar 15 mil crianças, recebeu ampla cobertura da imprensa e foi noticiada como a inauguração oficial da 'Campanha Nacional de Vacinação Oral contra a Poliomielite no Brasil' (Correio da Manhã, 1․9.1961, p. 2).

A controvérsia em torno da propriedade do uso da vacina Sabin no Brasil foi dirimida, alegando-se seu baixo custo, a inocuidade, a facilidade de administração, o efeito protetor mais prolongado e a capacidade de multiplicação no sistema digestivo, possibilitando a eliminação de vírus vacinal no ambiente. 
Avaliando positivamente as experiências anteriores, em 1961, o governo federal adquiriu três milhões de doses da vacina oral para ampliar a campanha de vacinação. Com essa iniciativa, recebeu moções de apoio de várias associações médicas do país. Decidiu-se então levar a efeito uma campanha na cidade do Rio de Janeiro, onde seriam aplicadas quinhentas mil doses da vacina Sabin em 250 postos, distribuídos pelos bairros da cidade, entre os dias 16 e 21 de outubro (Correio da Manhã, 6.10.1961, Caderno 1, p. 2).

Diariamente os jornais conclamavam a população a apoiar a campanha de vacinação: "O importante agora — e para isso convocamos com ênfase a população - é que todos dêem a sua cooperação para que o maior número possível de crianças, entre quatro meses e seis anos de idade, receba a proteção do produto criado pelo gênio do pesquisador emérito, dr. Albert Sabin, grande benfeitor da humanidade" (Correio da Manhã, 12.10.1961, Caderno 1, p. 6). Também publicavam os discursos de apoio de representantes de instituições médicas, como o de Amaro Azevedo, presidente da Federação de Homeopatia e do Instituto Hahnemanniano do Brasil (Correio da Manhã, 13.10.1961, p. 2).

"Uma gota, duas doses: uma criança sadia, livre da paralisia" foi o lema dessa campanha de vacinação, que contou com a colaboração de 2.500 voluntários e de diversas instituições, oficiais e particulares. A campanha recomendava que mesmo as crianças já imunizadas pelo processo Salk deveriam receber a vacina Sabin (Correio da Manhã, 15.10.1961, p. 3). Os jornais avaliaram a campanha como bem-sucedida e manifestaram a expectativa de que tomasse um âmbito nacional. Lembravam ainda a necessidade de as crianças vacinadas tomarem uma segunda dose após sessenta dias para assegurar a imunização.

A partir daí foram realizadas campanhas de vacinação em várias capitais brasileiras, uma por vez, com vacinas distribuídas pelo Ministério da Saúde. Esse processo não ocorreu sem percalços: ora o município agendava a campanha para aplicação da primeira dose, e a liberação das vacinas atrasava, como no caso de Belo Horizonte; ora desencontros entre o estado e o Ministério da Saúde inviabilizavam a aplicação da segunda dose de vacinas, como no caso do Rio de Janeiro, gerando polêmicas entre órgãos federais e estaduais (Correio da Manhã, 28.12.1961, p. 3).

Exatamente por causa dos problemas em relação ao suprimento e distribuição das vacinas, as primeiras campanhas se caracterizaram mais pela descontinuidade do que por um aumento gradativo da cobertura vacinal.

\section{O diagnóstico laboratorial da poliomielite}

Ainda em 1960, outra tecnologia de fundamental importância para o controle da poliomielite foi implantada no Brasil: a introdução da técnica de diagnóstico laboratorial do poliovírus (Schatzmayr et alii, 2002). 
Por meio de um convênio estabelecido entre a OPAS e o Instituto Oswaldo Cruz (IOC), foi criado o primeiro laboratório de diagnóstico para enterovírus, com as seguintes funções: o diagnóstico da poliomielite, pelo isolamento do poliovírus em amostras de fezes, e a diluição, envasamento e distribuição das primeiras vacinas orais contra a poliomielite que chegavam ao Brasil.

Em fins de 1964, o laboratório foi reformulado, voltando-se para pesquisas sobre o vírus herpes; contudo, o diagnóstico laboratorial da poliomielite não sofreu descontinuidade, pois os exames passaram a ser realizados no Instituto Noel Nutels. Com o apoio do CDC, de Atlanta, o laboratório foi novamente montado, dessa vez na Escola Nacional de Saúde Pública (ENSP), e em 1977, tornou-se laboratório central para enterovírus do Ministério da Saúde, voltando, no mesmo ano, a fazer parte do IOC.

Em excelente artigo, Schatzmayr et alii. (op. cit.) nos relatam a fundamental contribuição da Fiocruz para o controle e erradicação da poliomielite - com o laboratório de enterovírus do IOC - no que se refere à utilização de técnicas cada vez mais sensíveis e rápidas de diagnóstico do poliovírus. O mesmo ocorreu, mais adiante, com BioManguinhos, em relação ao aperfeiçoamento da formulação da vacina antipoliomielite oral.

\section{Plano Nacional de Controle da Poliomielite}

Como mostramos, as experiências anteriores de campanha contra a poliomielite sofreram grande descontinuidade a partir de 1961. Risi Jr. (2000, fita 2, lado A) afirma que "a história da poliomielite no Brasil, depois da vacina, era mais ou menos essa: você tinha uma epidemia e em seguida uma epidemia de vacinação". Dessa forma, a aplicação da

${ }^{11}$ João Batista Risi Júnior, médico epidemiologista, é um dos entrevistados do Acervo de Depoimentos Orais, constituído pelo projeto A História da Poliomielite e de sua Erradicação no Brasil, em que estão depositados 31 depoimentos, num total de noventa horas, de profissionais que estiveram e/ou estão envolvidos com a história da poliomielite no país. vacina chegava atrasada, isto é, quando a epidemia já estava em declínio. ${ }^{11}$

Além disso, as crianças dos segmentos mais favorecidos da população, as mais suscetíveis à forma paralítica, eram vacinadas por seus pediatras, o que resultava numa mudança no perfil da doença, que passou a incidir basicamente nas classes menos favorecidas da população, causando um impacto social menor. Talvez por isso não resultasse em uma política efetiva de combate à doença. Soma-se a isso a dificuldade decorrente das dimensões territoriais e da diversidade existente no país, requerendo grandes quantidades de vacina e uma estrutura de serviços de saúde que, à época, eram insuficientes.

Em 1971, face à ocorrência de repetidos surtos da doença em vários pontos do território nacional, o Ministério da Saúde instituiu o Plano Nacional de Controle da Poliomielite. Esse plano foi a primeira tentativa organizada nacionalmente de controlar a poliomielite no Brasil. Naquele ano, um projeto-piloto implantado no estado do Espírito Santo incluía um estudo para avaliar a resposta sorológica à vacina e 
introduzir a metodologia de campanhas estaduais realizadas em um só dia (Ministério da Saúde, 1993, p. 12).

O governo federal assegurou o suprimento de vacinas e a supervisão técnica, adotando a estratégia de vacinação em massa num só dia, nas zonas urbanas, e estabelecendo três etapas anuais de vacinação do grupo etário de três meses a quatro anos de idade, realizadas em períodos distintos nos diversos estados. Como a execução era de responsabilidade dos estados e municípios, seria necessário um trabalho de sensibilização das autoridades locais e de convencimento da população, inclusive para mobilizar recursos comunitários.

Em 1971 ocorreu somente a experiência do Espírito Santo; porém, em 1972 e 1973, o plano foi executado em 14 estados. A avaliação, do ponto de vista de cobertura, foi bastante positiva. O impacto dessas campanhas na incidência da doença revelou-se de difícil avaliação, como reconhece Risi Jr.(2000), uma vez que não se dispunha de dados epidemiológicos prévios no país.

Ao ser implementado o Programa Nacional de Imunização (PNI), em 1973, este incorporou o controle da poliomielite e introduziu a multivacinação, incluindo principalmente a vacina do sarampo como estratégia de campanhas. O PNI foi uma das iniciativas da gestão do ministro Mário Machado Lemos, que se caracterizou pela elaboração de grandes planos para a Saúde. O programa teve o objetivo de estimular e expandir a utilização de agentes imunizantes no país, como decorrência do Plano Decenal de Saúde para as Américas, discutido na $3^{\underline{a}}$ Reunião de Ministros de Saúde das Américas, realizada em 1972, no Chile. O plano incluía a proposta de redução da morbidade e mortalidade por doenças evitáveis por imunização.

Em 1974, a estratégia de campanha foi abandonada, priorizandose a vacinação de rotina pela rede básica de saúde. Paulo de Almeida Machado assumiu o Ministério da Saúde, e com ele um grupo de técnicos de São Paulo, com forte influência da Faculdade de Saúde Pública da Universidade de São Paulo, que defendia tenazmente a atuação do centro de saúde, as ações de rotina e a educação sanitária.

A avaliação de perdas e ganhos da mudança de estratégia é relativa. Se, por um lado, havia-se perdido na cobertura vacinal - até porque não se dispunha de serviços de saúde de rotina suficientes no país , por outro, ganhou-se na normalização técnica no que diz respeito à vacinação, à conservação da vacina na rede de frio e principalmente à vigilância epidemiológica. Em 1975, foram estabelecidas atividades de vigilância que incluíam normas técnicas para a confirmação clínica e laboratorial dos casos e investigação epidemiológica em âmbito nacional. 


\section{Implantação do Sistema de Vigilância Epidemiológica}

12 Epidemiologista norte-americano, considerado um dos principais mentores do desenvolvimento da vigilância como instrumento de saúde pública.

${ }^{13}$ Epidemiologista tcheco, é considerado, juntamente com Langmuir, um dos principais responsáveis pela ampla difusão da vigilância como instrumento de saúde pública.
Alexander Langmuir ${ }^{12}$ definiu em 1963 o conceito de vigilância como "a observação contínua da distribuição e tendências da incidência de doenças mediante a coleta sistemática, consolidação e avaliação de informes de morbidade e mortalidade, assim como de outros dados relevantes, e a regular disseminação dessas informações a todos os que necessitam conhecê-la" (Thacker e Berkelman, 1992, p. 73).

Karel Raska, ${ }^{13}$ em 1964, avançou no conceito, ao propor que a informação fosse acompanhada de 'intervenção', noção que denominou 'vigilância epidemiológica'. O conceito foi incorporado pela OMS, ao criar, em 1965, sua Unidade de Vigilância Epidemiológica da Divisão de Doenças Transmissíveis. Em 1968, a vigilância epidemiológica foi tema da $21^{\underline{a}}$ Assembléia Mundial de Saúde, que promoveu ampla discussão de sua aplicação no campo da saúde pública, resultando na recomendação de sua utilização a outros eventos, e não só às doenças transmissíveis. A vigilância nas formas propostas por Langmuir e Raska desenvolveu-se e consolidou-se, apresentando variações na sua abrangência em países com diferentes sistemas políticos, sociais e econômicos, e com distintas estruturas de serviços de saúde.

Foi nesse contexto que, em 1968, a Fundação de Serviços Especiais de Saúde Pública (FSESP) criou o Centro de Investigações Epidemiológicas. Este partiu da medida básica: a notificação obrigatória dos casos das doenças, realizada semanalmente pelas secretarias estaduais de Saúde. Entre elas, incluía-se a notificação da poliomielite, que, segundo observação de Risi Jr., "teve mais a ver com o novo conceito de vigilância epidemiológica do que com a própria poliomielite".

Até 1974, a maioria dos estados apenas notificava os casos. Não havia vigilância ativa e sistemática, investigação dos casos notificados, diagnóstico laboratorial, e tampouco outras atividades essenciais. Em 1975, no contexto de uma proposta de reordenação do setor saúde em que foi instituído o Sistema Nacional de Saúde (Escorel,1998), a FSESP implantou o Sistema Nacional de Vigilância Epidemiológica, incluindo a da poliomielite, o qual estabeleceu normas técnicas referentes à notificação, investigação dos casos, confirmação laboratorial e avaliação de seqüelas. Isso exigiu uma rede de laboratórios de saúde pública com a responsabilidade do diagnóstico da infecção pelo poliovírus nas amostras de sangue e fezes dos casos.

Assim, entre 1975 e 1979, pôde-se estudar de forma mais aprofundada as características epidemiológicas da poliomielite no Brasil, não só no tempo e espaço, mas também em relação a outras importantes variáveis, como idade, estado vacinal prévio, tipo de poliovírus isolado e seqüelas. Verificou-se que a poliomielite incidia mais nas crianças do grupo etário de zero a quatro anos, com 
14 Waldir Arcoverde nasceu no Piauí, mas fez toda sua carreira profissional no Rio Grande do Sul, onde a saúde pública era bastante desenvolvida. Foi diretor de Planejamento da Secretaria Estadual de Saúde do Rio Grande do Sul e representante da FESP neste estado.
15 Risi, em seu depoimento, ratifica a posição de Rosenberg quando diz que o secretário de Saúde do Paraná "adotou uma posição política 'diferente do normal'; o normal era o secretário sempre providenciar uma campanha e dizer que o assunto estava controlado e tal... (fita 2 , lado B, grifos nossos). predominância na faixa de seis meses a dois anos, não vacinadas, que viviam em zonas urbanas e era causada principalmente pelo poliomielite vírus 1 (Risi Jr., 1980). A análise dos dados disponíveis demonstrou ainda que a vacinação realizada nos últimos anos pela rede de serviços básicos de saúde era insuficiente para promover o controle da poliomielite, tendo ocorrido várias epidemias em diversos estados nesse período, totalizando, só no ano de 1975, 3.400 casos.

Dada a gravidade do problema no Brasil, reconhecido inclusive pela OMS, somada à repercussão nacional das epidemias que eclodiram no sul do país em dezembro de 1979, o recém-empossado ministro da Saúde Waldir Arcoverde tomou a iniciativa de enfrentar decididamente a questão da poliomielite no Brasil.

\section{Os dias nacionais de vacinação}

Ao assumir o Ministério da Saúde, ainda no primeiro ano de governo do presidente João Baptista Figueiredo, Waldir Arcoverde, sanitarista com experiência no Rio Grande do Sul, ${ }^{14}$ convidou Mozart Abreu Lima para ocupar o cargo de secretário-geral do ministério. Homem do planejamento, respeitado na área da saúde tanto pelos grupos conservadores (que defendiam a privatização da Saúde) quanto pelos progressistas (que propugnavam uma reforma que possibilitasse a universalização dos serviços), Mozart teve um papel fundamental na arquitetura do ministério.

Sua estratégia foi compor uma equipe que sustentasse a administração de Arcoverde, tanto do ponto de vista de penetração e liderança política quanto da qualificação técnica para enfrentar com competência os problemas na área (Lima, 2002, fita 3, lado A). Além disso, buscou-se uma forte aliança com a Fundação Oswaldo Cruz (Fiocruz), que, com expertise no campo da virologia, da epidemiologia e da logística, supriria diferentes lacunas existentes no conhecimento da equipe que assumia o ministério. Dessa forma, "a Fiocruz representou um papel fundamental nesse processo, calafetando e preenchendo as lacunas da equipe e dando toda a sustentação técnico-científica para sua atuação" (idem) .

A nova equipe do Ministério da Saúde logo deparou com uma importante epidemia de poliomielite no Paraná e em Santa Catarina, estados que mantinham um nível de vacinação bastante razoável. Porém, ao contrário do esperado - como aponta Rosenberg (op.cit.) em relação ao primeiro momento de uma epidemia, em que as autoridades tentam negá-la — ${ }^{15}$ o secretário de Saúde do Paraná, Oscar Alves, denunciou na televisão a existência da epidemia, o que produziu grande repercussão nacional em fins de 1979 e início de 1980.

Deve-se considerar que o regime militar - que vinha enfrentando grave crise política e econômica desde o início do governo Geisel, com o aumento das tensões sociais - estava em processo de abertura e interessado em lançar mão de políticas sociais para sua legitimação. 
Além disso, deve-se ressaltar a importância, do ponto de vista político, de uma equipe recém-chegada no governo dispor de condições para desenvolver uma ação com resultados concretos e rápidos.

Criou-se então uma configuração favorável ao enfrentamento da poliomielite no Brasil. Dessa forma, uma estratégia básica foi definida nos primeiros dias do mês de janeiro de 1980: vacinação em massa, em curtíssimo período de tempo, em todo o território nacional (Becker, 2002, fita 2, lado A).

Tão logo foi definida a estratégia, iniciaram-se as negociações em busca de apoio técnico e político. O ministério convidou Albert Sabin para assessorar a equipe no aprimoramento do modelo de intervenção. Sabin, tão logo assumiu sua tarefa no Brasil, no início de fevereiro, discordou das informações do Ministério da Saúde sobre a poliomielite — que, a seu ver, inviabilizavam uma ação de controle eficaz sobre a doença. Propôs uma pesquisa sobre prevalência de seqüelas em escolares, abrangendo todo o país, para estimar a magnitude da doença no território nacional, e, a partir dá, definir as ações de controle da poliomielite.

Os técnicos do ministério achavam que os dados disponíveis permitiam identificar o problema e determinar diretrizes básicas de um programa de controle. Além disso, a pesquisa proposta por Sabin demandava tempo e recursos naquele momento impraticáveis, porque devia-se postergar uma intervenção que se tornava urgente (Risi Jr., 1980).

A polêmica estava criada. Sabin deixou Brasília "sem se despedir da equipe" e veio para o Rio de Janeiro, de onde passou a atacar o ministro Arcoverde pela imprensa. Em carta ao presidente da República, Sabin defendia a exatidão dos dados estatísticos, considerando que, "assim como em operações militares, informes inexatos sobre inimigos podem levar a desastres, o mesmo ocorre quando se trata de combater uma doença epidêmica" ( $O$ Globo, 28.3.1980).

A imprensa abriu espaço para a controvérsia ao longo do mês de março. A opinião pública nacional e internacional fez coro com Sabin, com duras críticas ao ministério. Waldir Arcoverde saiu em defesa do programa. Em exposição sobre o controle da poliomielite no Brasil feita no plenário da Câmara dos Deputados no dia 23 de abril de 1980 - resumiu a situação epidemiológica da pólio e justificou a decisão pelos dias nacionais de vacinação (DNVs). Reforçava que "dados publicados pela OMS mostram que, depois da Índia, o Brasil foi o país que registrou o maior número de casos de poliomielite, em todo o mundo, no período de 1976 a 1978". Dizia ainda que "a análise detalhada dos dados fornecidos através do sistema de vigilância epidemiológica propicia entre outras indicações que a ocorrência da poliomielite no país não tende ao controle, se for mantida exclusivamente a estratégia de vacinação de rotina" (Brasil, Câmara dos Deputados, 1980). 
O ministro manteve-se no cargo e considerou que o "caso Sabin alertou o povo" e "contribuiu para criar uma consciência social sobre o problema da poliomielite paralítica e sobre a necessidade da vacinação em massa" (Jornal do Brasil, 22.5.1980). Nesse caso, não só o povo, como disse Arcoverde, mas também grande parte da comunidade científica, que, no final, se viu ferida em seus brios com as críticas de Sabin, acabou apoiando o programa do governo para o controle da poliomielite, configurado nos dias nacionais de vacinação (DNVs).

Para se chegar a esses dias houve um trabalho, segundo as palavras do próprio ministro, "monumental", tanto para montar a infra-estrutura de armazenagem, controle de qualidade e distribuição das vacinas e demais insumos necessários, como para negociar com os outros ministérios - principalmente o de Planejamento, com vistas à liberação de recursos financeiros, e o de Relações Exteriores, para importação das vacinas - e com os estados.

Iniciou-se um processo intenso de negociação política entre o Ministério da Saúde e os estados no plano de governadores e secretários de Saúde. O ministro da Saúde viajou a todos os estados para conseguir que os governadores priorizassem a campanha contra a poliomielite (Lima, 2002, fita 2, lado B). Era imprescindível que os estados compactuassem com essa estratégia de dias nacionais de vacinação, à medida que a execução estaria a seu encargo. O Ministério da Saúde entrava com os recursos materiais necessários, inclusive o suprimento de vacinas e o apoio logístico.

Sem dúvida houve quem se posicionasse contra a proposta. Sanitaristas, que defendiam a atenção primária à saúde como política adequada para a melhoria integral da qualidade de vida das populações, consideravam a estratégia de campanha prejudicial à conscientização e educação da população para as ações de saúde de rotina. Risi Jr. (2000, fita 3, lado A) identifica os opositores entre os sanitaristas da Escola de Saúde Pública da USP, que privilegiavam os serviços básicos de saúde, e, entre os participantes do movimento da reforma sanitária, os seguidores da Declaração de Alma-Ata, que preconizavam a participação comunitária para alcançar a 'saúde para todos' no ano 2000. Ele ressalta que a OMS, que havia promovido a conferência internacional na cidade de Alma-Ata, também se posicionara contra a idéia de 'dia nacional'.

Contudo, todos os recursos e apoios possíveis foram mobilizados para a realização dos dias nacionais de vacinação; desde o nível central, com o apoio de todos os órgãos ministeriais, até clubes de serviço, como o Rotary e o Lions, e grupos comunitários em nível local. As sociedades de pediatria também desempenharam um importante papel de apoio, ao se engajarem nesse esforço. Assim, nos dias 14 de junho e 16 de agosto de 1980, realizaram-se, respectivamente, a primeira e a segunda etapas de vacinação, em crianças entre zero e cinco anos de idade, independentemente de vacinação prévia, em um só dia, em todo território nacional. 
Em conseqüência disso, houve uma acentuada redução do número de casos da doença, que passou de 1.290, em 1980, para 122, em 1981. No ano seguinte, observou-se o menor número de casos já registrado nacionalmente: 45 confirmados. Os opositores se calaram. A estratégia dos dias nacionais de vacinação passou a se repetir a cada ano, e, assim, o número de casos se aproximou de zero.

Em 1984 verificou-se um aumento de casos em cidades do Nordeste, atribuído à baixa cobertura vacinal e a problemas de conservação de vacina. Acrescentou-se mais um dia de vacinação na região, que ficou conhecido como Dia Nordestino de Vacinação, mas o número de casos continuou aumentando. Em 1986, chegaram a seiscentos.

A OPAS/OMS, que recomendara a erradicação da transmissão do poliovírus selvagem na região das Américas baseada no modelo brasileiro, enviou um epidemiologista do CDC para reforçar a investigação sobre essa epidemia nordestina. A pesquisa laboratorial e o estudo epidemiológico realizados na Fiocruz e no CDC, em Atlanta, revelaram que a maioria das infecções fora causada pelo poliovírus 3. O seqüenciamento genético mostrou que esse vírus era típico da região das Américas e de outras regiões do cinturão tropical, ou seja, não se tratava de um vírus novo (Patriarca et alii, 1988). A solução, portanto, foi uma reformulação da vacina, isto é, a vacina que se usava tinha predominância de sorotipo 1, e a epidemia estava sendo causada pelo tipo 3 .

A possibilidade de predominância de um determinado poliovírus induzida pela própria vacina já havia sido sugerido por Alexander Langmuir e Russel Alexander no início de 1960. Ao realizarem nos Estados Unidos um levantamento epidemiológico da doença, em 1959, eles constataram um aumento sensível do número de casos de poliomielite nos últimos dois anos da pesquisa, apesar do emprego contínuo da vacina Salk desde 1955. Assim, formularam a seguinte hipótese: a vacina teria uma capacidade protetora menor para determinados tipos de poliovírus e, por isso, em razão do emprego em massa da vacina, estes teriam se tornado prevalentes ( $O$ Estado de $S$. Paulo, 3.7.1960, p. 3).

A contribuição da Fiocruz foi fundamental para solucionar a epidemia no Nordeste. Bio-Manguinhos, que desenvolvia a formulação da vacina a partir de concentrado de vírus importado, pôde produzir rapidamente vacina monovalente tipo 3 e trivalente potencializada para o sorotipo 3, e, a partir daí, redefinir a formulação da vacina com seiscentos mil partículas infectantes do tipo 3. Aliás, a necessidade de se aumentar a quantidade de partículas do tipo 3 na vacina já havia sido demonstrada pelo mesmo grupo em 1967. Essa nova formulação foi adotada pela OPAS para todos os países da América Latina (Schatzmayr et alii, op.cit.).

O reconhecimento público dos dias nacionais de vacinação consagrou definitivamente essa estratégia, que continua a ser implementada sistematicamente no Brasil. Pode-se considerá-la uma 
exceção dentro do processo de instabilidade política e descontinuidade administrativa que sempre caracterizou o cenário institucional brasileiro. Adquiriu dimensão internacional, ao ser recomendada pela OPAS como modelo, quando da proposta de interrupção da transmissão do poliovírus selvagem na região das Américas.

\title{
A erradicação da poliomielite
}

O então diretor do Programa Ampliado de Imunizações da OPAS, Ciro de Quadros, tão logo constatou o impacto dos dias nacionais de vacinação, começou a investigar as possibilidades de ser lançado um programa de poliomielite nas Américas. Procurou articular-se com Donald Henderson, grande liderança da erradicação da varíola, que considerou a idéia impossível, pelo fato de a vacina contra a poliomielite não ser termoestável como a da varíola.

Porém, em fins de 1984, James Grant - diretor do Fundo das Nações Unidas para a Infância (Unicef), cujo programa Universal Childhood Imunization pretendia alcançar 90\% de cobertura vacinal em todos os países do mundo até 1990 - tomou a iniciativa de procurar a OPAS com o objetivo de firmarem um compromisso de alcançar essa meta nas América "para dar exemplo aos outros países do mundo, já que o continente estava melhor estruturado" (Quadros, 2001, fita 2, lado A). Concluíram que precisariam erradicar uma doença imunoprevenível para mobilizar a opinião pública internacional. Na opinião de Ciro de Quadros, esta deveria ser a poliomielite, sobre a qual alguns países já apresentavam experiências de sucesso no controle.

Evans (op.cit, p. 199) aponta fatores socioeconômicos e políticos favorecendo o controle de uma doença, quais sejam:

\begin{abstract}
A doença deve ter tanto um impacto econômico suficiente para motivar uma ação legislativa quanto um importante efeito emocional para estimular programas de controle; uma vacina de baixo custo, estável e aceitável pelo público, assegurada pelo governo e baseada em princípios biológicos seguros; o programa de controle deve estar adequado a outras prioridades sociais e econômicas e a outros programas de saúde preventiva e curativa; deverá haver pessoal suficiente treinado ou a ser treinado para administrar e executar o esforço e, finalmente, deve haver força política suficiente que levará o programa até uma conclusão bem-sucedida.
\end{abstract}

Então, com força política suficiente, a OPAS anunciou a meta de erradicar a transmissão do poliovírus selvagem das Américas até 1990. Na XXXI Reunião do Conselho Diretivo da OPAS, realizada em setembro de 1985, os países-membros aprovaram e se comprometeram com essa iniciativa, que contaria com o apoio do Unicef, Usaid, BID e Rotary Internacional. 
No Brasil, em 1986, foi criado o Grupo de Trabalho para a erradicação da poliomielite (GT-poliomielite), com o objetivo de dar maior eficiência ao programa de vacinação, fazer um acompanhamento mais refinado do comportamento epidemiológico da poliomielite e desencadear as medidas de controle necessárias, supervisionadas e avaliadas adequadamente.

Em março de 1989 foi notificado o último isolamento do poliovírus selvagem no país, no município de Souza, na Paraíba. No mesmo ano, foram realizadas 302 operações-limpeza em municípios brasileiros, sendo 141 na região Nordeste. Durante estas operações-limpeza foram vacinadas mais de um milhão e quatrocentas mil crianças menores de cinco anos. A partir de 1990 até 1993, foram realizadas 154 operações-limpeza em municípios de ocorrência de casos de paralisias flácidas agudas clinicamente compatíveis com poliomielite, com a finalidade de revisar os casos confirmados e, posteriormente, os poliocompatíveis, assim como aqueles casos duvidosos. Para isso, foi criada em agosto de 1989 a Comissão Nacional de Revisão de Casos de Poliomielite.

A partir de 1990, embora mantendo as estratégias utilizadas até então para alcançar a erradicação da poliomielite, o Brasil direcionou o programa para o cumprimento dos critérios estabelecidos pela Comissão Internacional de Certificação da Erradicação da Poliomielite, recebendo em 1994 a Certificação da Erradicação da Poliomielite.

Ao comentar a erradicação da poliomielite nas Américas, Quadros (2001, fita 2, lado B) afirma que

a erradicação da poliomielite não foi, em si, um objetivo único. A erradicação foi um dos objetivos. O segundo foi reforçar o programa nacional de vacinas, ou seja, alcançar a imunização universal, e um outro era mobilizar a sociedade ... de mudar um pouco a mentalidade dos governos, de mudar a mentalidade da população. São três objetivos fundamentais, dos quais a erradicação já foi alcançada, ... o programa de vacinação saiu fortalecido, e a mobilização política e social eu acho que também se avançou bastante ..., isso significou que realmente, politicamente, a vacina ficou como uma coisa importante ... e a prevenção também.

A opinião de Quadros é ratificada pelo Relatório Taylor (The Taylor Commission Report). A OPAS nomeou uma comissão independente, presidida por Carl Taylor, redator da Declaração de Alma-Ata, para avaliar o impacto da erradicação da poliomielite nas Américas. Depois de dois anos de trabalho, o informe chegou a um resultado bastante positivo, demonstrando que um programa de erradicação de uma doença, quando bem conduzido, pode modificar todo um sistema de saúde e que, nos países avaliados, como conseqüência, a população desenvolveu uma cultura de prevenção. Esse relatório foi importante também, segundo Quadros (2001), para o convencimento das organizações que resistiam a dar o seu apoio a 
Agradecemos a Fernanda Lima Rabelo e Tamara Rangel Vieira, alunas do curso de história da UFF e bolsistas do Programa Institucional de Bolsas de Iniciação Científica (Pibic), pela pesquisa e coleta das fontes. um programa mundial de erradicação da poliomielite, principalmente no continente africano.

\section{Conclusão}

O significado da erradicação da poliomielite nas Américas transcende sua contribuição direta à saúde: foi uma demonstração da capacidade de realização deste setor quando as condições necessárias se fizeram presentes, principalmente liderança e decisão política adequadas.

Ao estudarmos a história da poliomielite e de sua erradicação, percebemos a complexidade de aspectos envolvidos: políticos, sociais, culturais, científicos e econômicos. A 'aventura da vacinação' não existiria sem uma validação política, sem a ativação de uma forma de pacto social.

A política de erradicação da poliomielite nas Américas foi uma ação bem-sucedida do setor saúde que eliminou do continente americano uma doença que produzia incapacidade física permanente. Portanto, o registro e o resgate da história da poliomielite são de fundamental importância, não só para o conhecimento acadêmico, mas também como produção de um legado à sociedade como um todo. O estudo histórico desse processo é ainda mais relevante, à medida que, hoje, suas lideranças já discutem as estratégias de suspensão da vacinação contra a poliomielite.

\section{REFERÊNCIAS BIBLIOGRÁFICAS}

PERIÓDICOS

Brasil Médico, XXIV, 47, pp. 467-8. 1910

Correio da Manhã, 1961, 1953, 1939

O Estado de S. Paulo, 1937, 1960

Jornal do Brasil, 1980

O Globo, 1980

DEPOIMENTOS ORAIS

Becker, Roberto 2002

Lima, Mozart de Abreu 2002

Quadros, Ciro de 2001

Risi Jr., João Batista 2000
Acervo de Depoimentos Orais: História da poliomielite e de sua erradicação no Brasil. Rio de Janeiro, Casa de Oswaldo Cruz/DAD/Arquivo Sonoro.

Acervo de Depoimentos Orais: História da poliomielite e de sua erradicação no Brasil, Rio de Janeiro, Casa de Oswaldo Cruz/DAD/Arquivo Sonoro.

Acervo de Depoimentos Orais: História da poliomielite e de sua erradicação no Brasil, Rio de Janeiro, Casa de Oswaldo Cruz/DAD/Arquivo Sonoro.

Acervo de Depoimentos Orais: História da poliomielite e de sua erradicação no Brasil, Rio de Janeiro, Casa de Oswaldo Cruz/DAD/Arquivo Sonoro. 


\section{ARTIGOS E LIVROS}

Barreto, João de Barros 1953

Beale, A.

1996

Bodian, D.

1952

Bodian, D.

Brasil, Câmara dos

Deputados

1980

Brasil, Ministério

da Saúde

1988

Enders, J. F. et alii 1949

Escorel, Sarah

1998

Evans, Alfred

1985

Figueira, Antônio

Fernandes

1911

Gomes Jr., Francisco de Salles

Hinman, Allan R. et al July 15, 1995

Karlen, Arno

1996

Koprowski, Hylary

e Plotkin, Stanley

1996

Lima, Mozart Abreu 2002

Ministério da Saúde 1993

Ministério da Saúde 1988

Moulin, Anne

Marie (org.) 1996
'Progressos e percalços no campo da poliomielite'.

Revista de Higiene e Saúde Pública, vol 12 nº-1-4, pp. 21-33.

'Histoire du vaccin polio injectable'. Em Anne Marie Moulin (org.), L'aventure de la vaccination. Paris, Fayard, cap. XXI, pp. 311-8.

'A reconsideration of the pathogenesis of poliomyelitis'.

American Journal of Hygiene, 55:414.

'Differention of types of poliomyelitis viruses. Reinfection experiments in monkeys (second attacks)'. American Journal of Hygiene, vol. 49, ํㅡㄴ 200.

Exposição do Ministério da Saúde na Câmara dos Deputados. Brasília.

Bases técnicas para a erradicação da transmissão autóctone da poliomielite. Brasília, Centro de Documentação do Ministério da Saúde.

'Cultivation of the Lansing strain of poliomyelitis virus in cultures of various human embryonic tissues'. Science, vol. 109, no 85 .

Reviravolta na saúde. Origem e articulação do movimento sanitário. Rio de Janeiro, Editora Fiocruz.

'The eradication of communicable diseases: myth or reality?'. American Journal of Epidemiology, vol. 122, $\mathrm{n}^{\circ}$ 2, pp. 199-207.

Doença de Heine-Medin no Rio de Janeiro.

Rio de Janeiro, Tipografia do Jornal do Commércio.

Epidemia de polyomielite infantil em Villa Americana.

São Paulo, Serviço Sanitário do Estado/Oficinas Gráficas Olegário Ribeiro.

'Invited Commentary on The Cutter incident: poliomyelitis following formaldehyde- inactivated poliovirus vaccination in United States during the spring of 1955. II Relatioship of Poliomielytis to Cutter vaccine'. American Journal of Epidemiology, vol. 142, nํㅡ 2, pp. 107-8.

Man and microbes: disease and plagues in history and modern times.

Nova York, Toutchstone.

'Histoire alternative du vaccin oral'. Em: Anne Marie Moulin (org.), L'aventure de la vaccination. Paris, Fayard, cap. XX, pp. 300-9.

Acervo de depoimentos orais: história da poliomielite e de sua erradicação no Brasil. Casa de Oswaldo Cruz/DAD/Arquivo Sonoro.

Programa Nacional de Imunizações - 20 anos.

Brasília.

Bases técnicas para a erradicação da transmissão autóctone da poliomielite. Brasília, Centro de Documentação do Ministério da Saúde.

L'aventure de la vaccination.

Paris, Fayard. 
Nathanson, Neal e

Langmuir, Alexander D. July 15, 1955

Parreiras, Décio

1942

Parreiras, Décio

1940

Patriarca, P. A. et alii Feb. 27, 1988

Risi Jr., J. B.

18.4.1980

Robbins, Frederick C. 1999

Rogers, Naomi

1996

Rosenberg, Charles E. 1992

Shaeffer, M. Li C. P.

Schatzmayr, H. G. et alii jan.-abr. 2002

Thaker e Berkelman 1992

Vieira, Francisco Borges 1940
'Historical paper The Cutter incident: poliomielitis following formaldehydeinactivated poliovirus vaccination in United States during Spring of 1955. II. Relationship of poliomielytis to Cutter vaccine'. American Journal of Epidemiology, vol. 142, nำ 2, pp. 109-40.

Atividades de bigiene pública no Rio de Janeiro, 1939-1949. Rio de Janeiro, Oficinas Gráficas Alba.

'Doença de Heine-Medin: epidemia no Rio de Janeiro em 1939 (anotações e estudos)'. A Folha Médica, vol. XXI, nº 20.

'Randomised trial of alternative formulations of oral poliovaccine in Brasil'. The Lancet.

'Considerações sobre a consultoria prestada pelo doutor Sabin ao Ministério da Saúde. Esclarecimentos necessários em face das repercussões de seu afastamento'. Brasília.

'The history of polio vaccine development'. Em Stanley A. Plotkin et al. (org.), Vaccines/, p. 14.

Dirt and disease: poliomielite before FDR.

New Brunswick, Rutgers University Press.

Explaining epidemics and other studies in the history of medicine. Cambridge, Cambridge University Press.

'Adaptation of tipe I poliomylites virus to mice'.

Proc. Soc. Exp Biol. Méd, vol. 82, no 477.

'Erradicação da poliomielite no Brasil: a contribuição da Fundação Oswaldo Cruz'. História, Ciências, Saúde - Manguinhos, vol. 9(1), pp. 11-24.

'History of Public Health Surveillance'. Em William Halperin (org.), Public Health Surveillance. Nova York, Van Nostrand Reinhold.

'Poliomielite aguda e sua incidência em São Paulo'.

Arquivos de Higiene e Saúde Pública, vol. 5, nº 9 .

Recebido para publicação em setembro de 2002.

Aprovado para publicação em julho 2003. 